\title{
Molecular cloning of a determinant coding for fimbrial antigen F165, a Prs-like fimbrial antigen from porcine septicaemic Escherichia coli
}

\author{
Josée Harel, ${ }^{*}$ Céline Forget, Josée Saint-Amand, France Daigle, Daniel Dubreuil, \\ MARIO JACQUES and JOHN FAIRBROTHER
}

Department of Pathology and Microbiology, Faculty of Veterinary Medicine, University of Montreal, PO Box 5000, Saint-Hyacinthe, Quebec, Canada J2S 7 C6

(Received 9 September 1991; revised 19 February 1992; accepted 11 March 1992)

\begin{abstract}
The genetic determinant coding for $\mathbf{F 1 6 5}_{1}$ fimbriae was cloned from the chromosome of the porcine Escherichia coli wild-type strain 4787 (O115: $\left.\mathrm{K}^{-}: \mathrm{H51}: \mathrm{F165}\right)$. The fimbrial determinant was further subcloned into the BamHI site of pACYC184 and a restriction map was established. On Southern hybridization, identity between the chromosomally encoded prs-like determinant of strain 4787 and its cloned counterparts was demonstrated. The cloned F165 $_{1}$ fimbriae and those of the wild-type strain possessed a major protein subunit of molecular mass

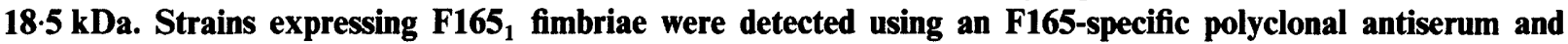
caused mannose-resistant haemagglutination and agglutination of Forssman latex beads. Antiserum against the

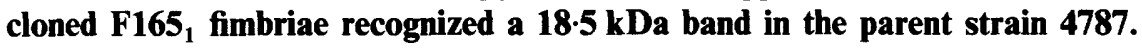

\section{Introduction}

Extra-intestinal Escherichia coli are a frequent cause of urinary tract infection, sepsis and newborn meningitis (NBM) (Ørskov \& Ørskov, 1985; Svanborg-Edén \& De Man, 1987). Extra-intestinal $E$. coli strains produce adhesins which mediate attachment to eukaryotic cells and which can be distinguished by their receptor specificity (Hacker, 1989; Tennent et al., 1990). Common F1A (type 1) fimbrial adhesins recognize $\alpha$-mannose in glycoproteins (Ørskov \& Ørskov, 1983), whereas mannose-resistant adhesins bind to eukaryotic receptor substances other than mannose. $P$ fimbriae, which represent the main group of mannose-resistant fimbriae associated with urinary tract infections, possess Gadhesins, which recognize the globo-series of glycolipids present on human erythrocytes possessing the $\mathbf{P}$ blood group antigen (Källenius et al., 1980; Väisänen et al., 1984; Strömberg et al., 1991). The prs operon, which is very similar to the operon coding for $\mathbf{P}$ fimbriae, encodes PrsG, which preferentially binds to the Forssman antigen, a major constituent on sheep erythrocytes (Lund et al., 1988; Lindstedt et al., 1989; Karr et al., 1989).

* Author for correspondence. Tel. (514) 7738521 ext. 233; fax (514) 7732161

Abbreviation: MRHA, mannose-resistant haemagglutination.
Another important group of mannose-resistant adhesins, the $S$ fimbrial adhesins, recognize an $\alpha$-sialyl- $(2 \rightarrow 3) \beta$ Gal-containing receptor structure and are commonly found on $E$. coli strains causing sepsis or newborn meningitis (Korhonen et al., 1984; Hacker et al., 1985). In addition to fimbrial adhesins, other adhesive proteins of extra-intestinal $E$. coli, which do not exhibit fimbrial structures, have been observed (Labigne-Roussel et al., 1984; Rhen et al., 1986).

A mannose-resistant fimbrial antigen, F165, on 0115 strains causing septicaemia in young pigs has been identified (Fairbrother et al., 1986). Fimbrial antigen F165 is found on $E$. coli strains isolated from piglets and calves with septicaemia and/or diarrhoea (Fairbrother $e t$ al., 1988b). F165 fimbriae are long, rigid and have a diameter of about 5 to $8 \mathrm{~nm}$ (Fairbrother $e t$ al., 1988a). The purified fimbrial complex consists of two separate protein subunits, with apparent molecular masses of 19000 and $17500 \mathrm{Da}$, which we have subsequently designated $\mathrm{F} 165_{1}$ and $\mathrm{F} 165_{2}$, respectively (Fairbrother et al., 1988a). It has been demonstrated that pap sequences or pap-related sequences are predominant in F165positive isolates from animals and may be found in association with $a f a$ or $s f a$ or related sequences (Harel $e t$ al., 1991a). F165-positive isolates may express multiple adhesins, two of which recognize the $\operatorname{GalNAc}(\alpha 1 \rightarrow 3)$ $\beta$ GalNAc moiety of the Forssman antigen and the $\mathrm{Gal}(\alpha \mathrm{l} \rightarrow 4) \beta \mathrm{Gal}$ moiety of the $\mathrm{P}$ blood group antigen 
respectively (J. Fairbrother and others, unpublished). Expression of the Forssman-recognizing adhesin appears to be associated with pathogenicity of F165positive strains in intraperitoneally inoculated adult mice and in orally inoculated newborn pigs (Fairbrother et al., 1989).

This study reports the cloning of a genomic DNA fragment required for the expression of $F 165_{1}$ fimbriae, one of the fimbrial components of F165 complex, which recognizes the GalNAc $(\alpha 1 \rightarrow 3)$ GalNAc moiety of the Forssman antigen, from a porcine septicaemic F165positive E. coli $\mathrm{O} 115$ strain.

\section{Methods}

Bacterial strains and plasmids. E. coli 4787 is a wild-type strain $\left(\mathrm{O} 115: \mathrm{K}^{-}: \mathrm{H} 51: \mathrm{F} 165\right)$ isolated from the intestinal contents of a diarrhoeic piglet. Strain 4787 was shown to contain P- and S-related nucleotide sequences (Harel et al., 1991a). E. coli HB101 hsdR hsdM recA13 supE44 lacZ4 leuB6 proA thi-1 $\mathrm{Str}^{\mathrm{r}}$ was used as the host in transfection and transformation experiments. Vector plasmids pMMB33 (Frey et al., 1983) and pACYC184 (Chang \& Cohen, 1978) were used for cloning experiments. Plasmid pPIL1006 carrying a papC gene internal fragment (Archambaud et al., 1988) was used in colony hybridization experiments.

Bacteria were cultivated in L-broth or on L-agar plates containing $1.5 \%(w / v)$ agar (Miller, 1972). Selective pressure against loss of plasmids was imposed by adding $50 \mu \mathrm{g}$ kanamycin $\mathrm{ml}^{-1}$ or $20 \mu \mathrm{g}$ chloramphenicol $\mathrm{ml}^{-1}$ to the medium. Strains were grown on minimal medium for maximal expression of F165 (Fairbrother et al., 1988a).

Cosmid cloning. Genomic DNA from E. coli 4787 was partially cleaved with the restriction enzyme Sau $3 \mathrm{~A}$ and ligated into the BamHI site of cosmid vector pMMB33 DNA digested with BamHI, HpaI and SmaI (Frey et al., 1983). Cosmids were packaged into phage $\lambda$ particles and used to infect $E$. coli HB101 (Hull et al., 1981). Following selection, subcloning was done into the BamHI site of pACYC184.

Isolation, transformation and analysis of plasmid DNA. The method of Birnboim \& Doly (1979) was used for isolation of plasmid DNA from $E$. coli $\mathrm{HB} 101$ host strains and wild-type F165-positive $E$. coli 4787 Plasmid DNA was extracted and purified by ultracentrifugation in caesium chloride/ethidium bromide gradients (Maniatis et al., 1982). Competent cells prepared by the calcium chloride/rubidium chloride method were used for plasmid transformation to $E$. coli (Kushner, 1978). Plasmids were digested with appropriate restriction endonucleases under conditions specified by the manufacturer (PharmaciaLKB). Electrophoretic analysis of plasmid DNA was performed using $0.7 \%$ agarose gels and Tris/borate buffer. Restriction fragments were purified by extraction from low melting agarose after electrophoresis (Lortie et al., 1991).

Southern hybridization and autoradiography. Transfer of DNA fragments from agarose gels to nitrocellulose filters, washing and autoradiography were done as described by Southern (1975). Stringent conditions were used for the washing procedure. Colony hybridizations were carried out as described by Harel et al. (1990). Appropriate DNA fragments were cut out of the gel, purified, and radiolabelled with $\left[\alpha^{-32} \mathrm{P}\right] \mathrm{dCTP}$ by using a random oligolabelling kit (Pharmacia-LKB) according to the manufacturer's instructions (Harel et al., 1991b).

Haemagglutination. Mannose-resistant haemagglutination (MRHA) was assessed essentially as described by Fairbrother et al. (1988a) using human $\mathrm{OP}_{1}$ and $\mathrm{A}_{1} \mathrm{P}_{1}$ erythrocytes, and porcine and ovine erythro- cytes. Erythrocytes were diluted to 3\%(v/v) suspensions in phosphatebuffered saline (PBS; $0.85 \% \mathrm{NaCl})$ containing $2.5 \%(\mathrm{w} / \mathrm{v})$ methyl $\alpha$-mannoside. Erythrocytes and bacterial suspensions $(20 \mu \mathrm{l}$ of each) were mixed on a glass slide. The slide was tilted and agglutination was observed visually.

Latex bead agglutination. Latex beads $(20 \mu \mathrm{l})$ coated with $\mathrm{Gal}(\alpha 1 \rightarrow 4) \mathrm{Gal} \beta$ (P1 BSA; Ag latex, Chembiomed, Canada) or $\operatorname{GalNAc}(\alpha 1 \rightarrow 3)$ GalNAc $\beta$ (Forssman disaccharide latex, Chembiomed) were mixed on a slide with an equal volume of bacterial suspension at $4{ }^{\circ} \mathrm{C}$. After tilting for $2 \mathrm{~min}$, agglutination was read (Labigne-Roussel et al., 1984). All reagents and suspensions were kept at $4^{\circ} \mathrm{C}$.

Antiserum production. Polyclonal antibodies were generated against F165 complex purified by FPLC from $E$. coli 4787 by injection of $10 \mu \mathrm{g}$ aliquots of purified proteins into rabbits as described previously (Fairbrother et al., 1986). To enhance the specificity of immunodetection of fimbrial proteins, the antibodies were absorbed against whole cells of strain 4787 grown at $18^{\circ} \mathrm{C}$. F165, fimbrial antiserum was prepared by immunization of rabbits with a crude fimbrial preparation from HB101(pIIIA9) as described previously (Contrepois et al., 1989). This antiserum was absorbed repeatedly with strain HB101 to remove antibodies not specific for the fimbrial antigen.

Immunocolony. Production of F165 by the clones was determined using an immunocolony technique on bacteria grown on MD-1 agar. Bacteria were spotted on nitrocellulose filters. After drying, the filters were saturated with $5 \%(\mathrm{w} / \mathrm{v})$ skim milk and incubated for $90 \mathrm{~min}$ at $25^{\circ} \mathrm{C}$ with $\mathrm{F} 165$ complex antiserum (dilution 1/1000) in Tris/buffered saline (TBS) (0.2 M-Tris/ $/ \mathrm{HCl}, 0.5 \mathrm{M}-\mathrm{NaCl}, \mathrm{pH} 7.5)$ containing $0.05 \%$ (v/v) Tween 20 (TTBS) plus $2.5 \%$ skim milk. Filters were then incubated for $1 \mathrm{~h}$ at $25^{\circ} \mathrm{C}$ in $1 / 5000$ diluted goat anti-rabbit immunoglobulin G. After a short wash in TTBS, the filters were incubated in 1/3000 avidine peroxidase. Finally, the filters were washed twice in TTBS and twice in TBS and treated with hydrogen peroxide substrate and 4-chloronaphthol chromogen.

Immuno-electron microscopy. A drop of a washed bacterial suspension was placed on Formvar-coated grids for $1 \mathrm{~min}$. The grids were then placed sequentially on drops of PBS containing $1 \%(w / v)$ ovalbumin for $5 \mathrm{~min}$ and a suitable dilution of rabbit F165 complex antiserum for $30 \mathrm{~min}$. Grids were washed and placed on drops containing gold colloidal particles $(10 \mathrm{~nm}$ ) conjugated to protein A (Sigma) for $30 \mathrm{~min}$. After a final washing step, the grids were stained with $1 \%(\mathrm{w} / \mathrm{v})$ phosphotungstic acid ( $\mathrm{pH} 7.0)$ and examined with an electron microscope (Phillips 201) at an accelerating voltage of $60 \mathrm{kV}$ (Broes $e t$ al., 1988).

Isolation of fimbriae, PAGE and immunoblotting. Crude fimbrial extracts were prepared from bacteria grown on MD-1 plates as described previously (Fairbrother et al., 1988a). After treatment of the fimbrial samples by boiling for $5 \mathrm{~min}$ in $10 \mathrm{~mm}$-Tris $/ \mathrm{HCl}(\mathrm{pH} \mathrm{7.8)}$ containing $4 \%(\mathrm{w} / \mathrm{v})$ SDS, $0.01 \mathrm{ml}$ mercaptoethanol, $0.2 \mathrm{ml}$ glycerol and $0.002 \%$ bromophenol blue, the samples were run on slab gels as described previously (Fairbrother et al., 1988a). Western blotting (immunoblotting) was carried out by the method of Towbin et al. (1979). Crude fimbrial extracts from wild-type $E$. coli $4787, E$. coli HB101(pIIIA9) and HB101(pCJ7) were electrophoresed on SDSpolyacrylamide gels. Following transfer to nitrocellulose filters, the electrophoresed preparations were reacted with F165 complex and

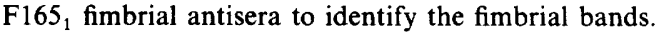

Amino acid composition analysis. Protein was electroblotted on Immobilon transfer membrane (Millipore) following the method of Legendre \& Matsudaira (1988). Amino acid sequencing of specific protein bands was done on an Applied Biosystems model 470A gas phase Sequanator running a standard operating program. Phenylthio- 
hydantoin derivatives were separated using an on-line PTH analyser (Applied Biosystems, model 900).

\section{Results}

Molecular cloning of the F165 fimbriae determinant

Genomic DNA was isolated from strain 4787 possessing the F165 fimbrial complex. After cleavage with Sau3A and a packaging procedure, $600 \mathrm{E}$. coli $\mathrm{K} 12$ colonies were screened for the components of the F165 complex by the immunocolony detection technique. One of the recombinant clones harbouring a cosmid, designated pIIIA9, that was found to react with F165 complex antiserum, was also pap-positive by colony hybridization. The expression by this clone of fimbriae reacting with F165 complex antiserum was confirmed by the isolation of fimbriae and by subsequent SDS-PAGE and immunoblotting with F165 antiserum. The MRHA haemagglutination and receptor binding properties (Table 1) indicated the presence of prs-like, rather than pap, coding genes.

The pIIIA9 DNA was further cleaved with the restriction enzyme $B a m H I$, and suitable fragments were ligated into the BamHI site of pACYC184. A recombinant plasmid, $\mathrm{pCJ} 7$, had lost tetracycline resistance, still expressed resistance to chloramphenicol and conferred on strain HB101 specific agglutination of Forssman latex beads and of ovine, porcine and human agglutination group $A_{1} P_{1}$ erythrocytes, and expression of fimbriae. Because of their haemagglutination and receptor binding properties, the clones derived from the pap-positive cosmid were described as prs-like clones. Electron microscopy showed that the surface of the bacteria was fimbriated. The structures could be identified by immunogold labelling experiments as F165 fimbriae using F165 complex antiserum (Fig. 1).

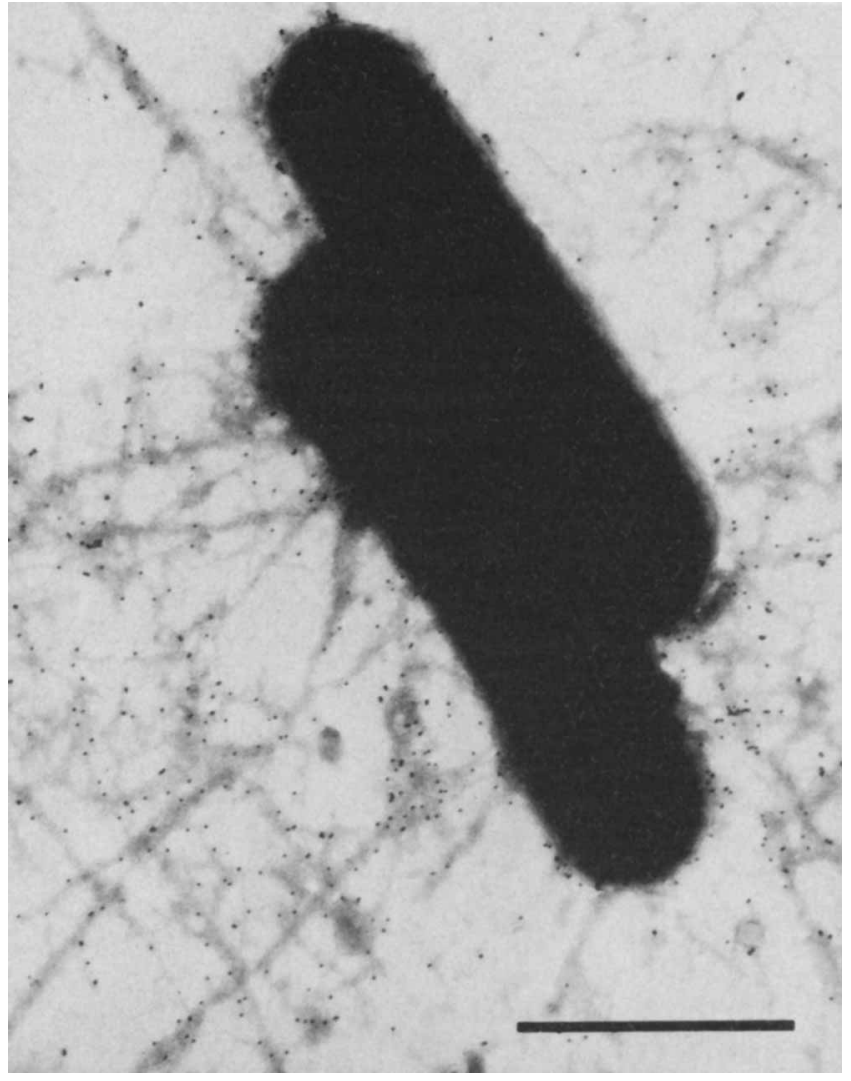

Fig. 1. Transmission electron micrograph of E. coli $\mathrm{HB} 101(\mathrm{pCJ} 7)$ labelled using the immunogold technique. Cells were incubated with antiserum raised against F165 fimbriae and then with protein A-gold $(10 \mathrm{~nm})$. Bar, $1 \mu \mathrm{m}$.

\section{Restriction map of $p C J 7$}

The recombinant plasmid $\mathrm{pCJ} 7$ consisted of the vector pACYC184 and a chromosomal insert of $10 \mathrm{~kb}$. The physical map of $\mathrm{pCJ} 7$ was further determined by digestion with different restriction enzymes (Fig. 2). The

Table 1. Characteristics of wild-type E. coli strain 4787 and subclones carrying various plasmids

\begin{tabular}{|c|c|c|c|c|c|c|}
\hline \multirow{3}{*}{$\begin{array}{l}\text { Strain/ } \\
\text { plasmid }\end{array}$} & \multirow{3}{*}{$\begin{array}{l}\text { Geno- } \\
\text { type }\end{array}$} & \multicolumn{3}{|c|}{$\begin{array}{l}\text { Mannose-resistant } \\
\text { haemagglutination }\end{array}$} & & \\
\hline & & \multicolumn{2}{|c|}{$\begin{array}{l}\text { Human } \\
\text { erythrocytes }\end{array}$} & \multirow{2}{*}{$\begin{array}{c}\text { Ovine } \\
\text { and } \\
\text { porcine } \\
\text { erythrocytes }\end{array}$} & \multicolumn{2}{|c|}{$\begin{array}{l}\text { Agglutination of } \\
\text { latex beads }\end{array}$} \\
\hline & & $\mathbf{A}_{1} \mathbf{P}_{1}$ & $\mathrm{OP}_{1}$ & & Gall $\rightarrow 4 \mathrm{Gal}$ & GalNAcl $\rightarrow 4$ GalNAc \\
\hline $4787 d$ & pap sfa & +++ & - & +++ & $(+)$ & ++ \\
\hline pIIIA9 & pap & + & - & + & - & +++ \\
\hline pCJ7 & pap & +++ & - & +++ & - & +++ \\
\hline HB101 & - & - & - & - & - & - \\
\hline
\end{tabular}



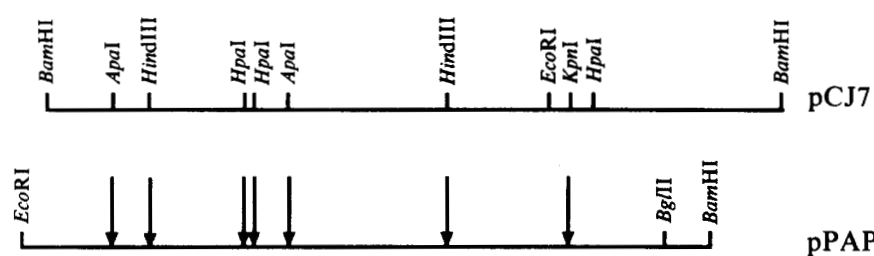

pPAP5

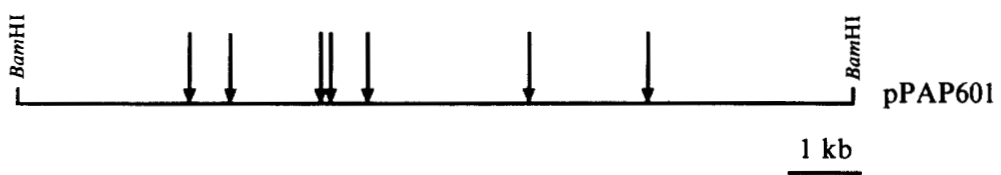

Fig. 2. Alignment of $F 165_{1}$, pap and prs gene clusters. Restriction sites which map at identical positions in the clusters are indicated with arrows on pPAP5 and pPAP601 (Lund et al., 1988).

results indicated that the prs-like gene cluster is physically related to both the pap and prs gene clusters (Lund et al., 1988; Lindstedt et al., 1989; Karr et al., 1989). A BglII site, which is present in papG but absent in prsG, was not found in $\mathrm{pCJ} 7$. In contrast to the prs operon, some restriction endonuclease sites, such as $H p a \mathrm{I}$ and $E c o$ RI sites, are found in the $3^{\prime}$ region of the F165 1 operon of pCJ7 (Fig. 2).

Pst I-cleaved chromosomal DNA of strain 4787 and pCJ7 plasmid DNA were hybridized against an $\alpha-32 \mathrm{P}-$ labelled probe for the $\mathrm{F} 165_{1}$ determinant from $\mathrm{pCJ} 7$, consisting of the $10 \mathrm{~kb} \mathrm{BamHI}$ fragment. As judged from the restriction maps of other cloned $P$ determinants which share some homology, this fragment carries most of the internal $F 165_{1}$ coding region. Identical Pst $\mathrm{I}$ fragments of $1.8,1.2,0.5$ and $0.3 \mathrm{~kb}$ were obtained from the genomic and recombinant plasmid DNA (Fig. 3).

The location of the genes expressing MRHA in the wild-type parent strain 4787 was determined. Strain 4787 was the host of at least five plasmids of different molecular masses. The plasmids were purified from strain 4787, digested with Pst I, and hybridized with the BamHI probe for pCJ7 (Fig. 3). None of the plasmidgenerated fragments exhibited homologous sequences. These results showed that the genes associated with MRHA expression in strain 4787 were not plasmidencoded and that four Pst I internal fragments from strain 4787 chromosomal DNA were present. Moreover, the $F 165_{1}$ operon was present in a single copy in wildtype strain 4787 , as demonstrated by a unique $19 \mathrm{~kb}$ Bam HI chromosomal band hybridizing with the $\mathrm{pCJ} 7$ $B a m H I$ probe and containing an internal EcoRI site (Fig. 3).

\section{Characterization of the F165 fimbriae}

After purification of the fimbriae and dissociation with SDS, an $18.5 \mathrm{kDa}$ protein band was obtained in PAGE from both the wild-type strain 4787 and the E. coli K12 clones harbouring pIIIA9 or pCJ7. A second band of
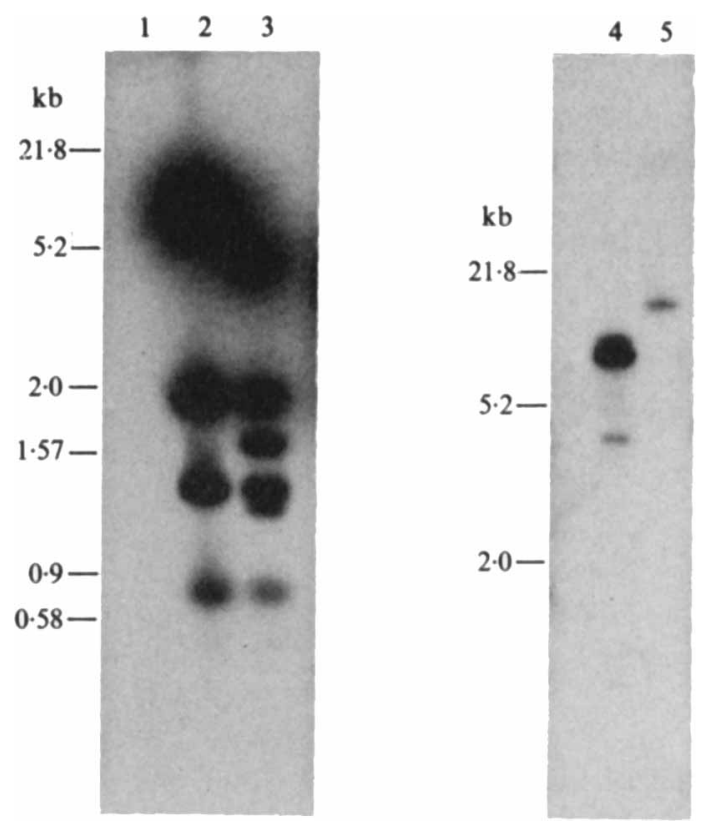

Fig. 3. Hybridization patterns of Pst I-cleaved plasmid DNA from E. coli strain 4787 (lane 1), HB101(pCJ7) (lane 2), chromosomal DNA from E. coli 4787 (lane 3), BamHI-cleaved (lane 4), and EcoRI-cleaved (lane 5) chromosomal DNA from $E$. coli 4787 . The hybridization probe was the $\alpha-{ }^{32}$ P-labelled $10 \mathrm{~kb} \mathrm{BamHI}$ fragment of $\mathrm{pCJ} 7$.

$17 \mathrm{kDa}$ was visible in preparations of $E$. coli 4787 . Wildtype strain 4787 and strains carrying the cloned prs-like determinant reacted strongly with the F165 complex antiserum in the immunocolony assay, whereas strain HB101 showed no reaction. Immunoblotting using F165 complex antiserum revealed two bands of $18.5 \mathrm{kDa}$ and $17 \mathrm{kDa}$ in the parent strain 4787 , whereas in subclone $\mathrm{HB} 101$ (pCJ7) only one band of $18.5 \mathrm{kDa}, \mathrm{F} 165_{1}$, was revealed (Fig. 4). Moreover, antiserum directed against F165 1 crude extract from HB101(pIIIA9) recognized only one band of $18.5 \mathrm{kDa}$ in the parent strain 4787 , and one band in HB101(pIIIA9) and HB101 (pCJ7) (Fig. 4). The second band of $17 \mathrm{kDa}$, visible in preparations of E. coli 4787 reacted with F165 complex antiserum, is the 
(a)

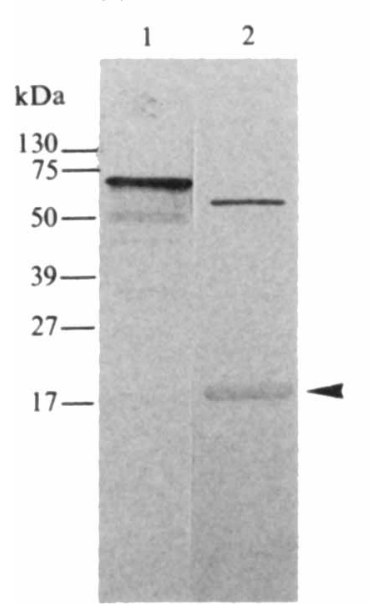

(b)

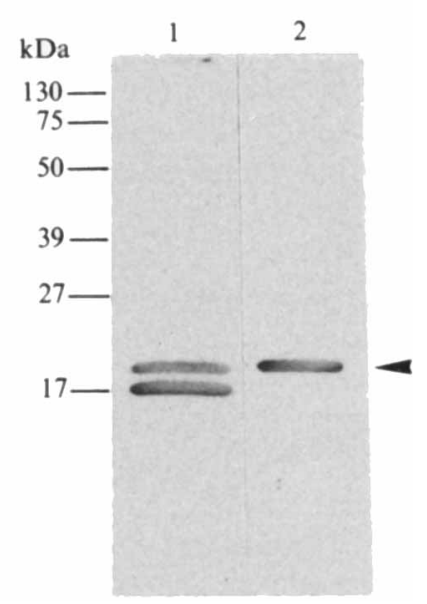

Fig. 4. Western blot of SDS-PAGE of fimbrial subunits from different $E$. coli strains. In (a) the nitrocellulose was reacted with rabbit $\mathrm{F} 165_{1}$ (Prs-like) antiserum to clone pIIIA9; in (b) the nitrocellulose was reacted with rabbit F165 antiserum to strain 4787 . Lanes 1 , strain 4787; lanes $2, \mathrm{HB} 10 \mathrm{l}(\mathrm{pCJ} 7)$. The position of the $18.5 \mathrm{kDa}$ band is indicated (4).

Table 2. Amino-terminal amino acid sequences of $F 165_{1}$, $\mathrm{PapA}, \mathrm{F}_{2}, \mathrm{FII}$ and $\mathrm{F} \mathrm{7}_{1}$ fimbriae

$a$, Båga et al. (1984); b, Van Die \& Bergmans (1984); $c$, Van Die $e t$ al. (1987); $d$, Rhen et al. (1985).

\begin{tabular}{lrrr}
\hline \hline & 5 & 10 & 14 \\
\hline F165 $_{1}$ & APTTP & QGQGI & VTFN \\
PapA $^{a}$ & APTIP & QGQGK & VTFN \\
F7 $^{b}$ & APTIP & QGQGK & VTFN \\
F11 $^{c}$ & APTIP & QGQGK & VTFN \\
F7 $^{d}$ & AASIP & QGQGE & VSFK \\
\hline \hline
\end{tabular}

major protein subunit of fimbrial component $\mathrm{F} 165_{2}$ (Harel et al., 1991a).

Amino-terminal amino acid sequencing revealed that from residue 1 to 14 , the sequence of the $18.5 \mathrm{kDa} F 165_{1}$ fimbrial major subunit closely resembled that of PapA (Båga et al., 1984), F11 (Van Die et al., 1987) and F7 (Van Die \& Bergmans, 1984) fimbriae and, to a lesser extent, that of $\mathrm{F} 7_{1}$ fimbriae (Rhen et al., 1985) (Table 2). The amino-terminal sequence differed from those of Pap, F11 and $F 7_{2}$ at two sites with a substitution of isoleucine for threonine at position 4 and a substitution of leucine for isoleucine at position 10.

\section{Discussion}

In this report, the molecular cloning of the gene encoding the F165, fimbrial component of the F165 complex from an $E$. coli strain that can cause septicaemia in pigs is described. After a cosmid cloning procedure, a $10 \mathrm{~kb}$ piece of DNA was inserted into the BamHI site of pCAYC184. This chromosomal DNA insert conferred MRHA specific for Forssman adhesins ( $F$ adhesins) and the formation of fimbriae related to $P$ fimbriae. On the basis of restriction sites, some similarities were revealed between the cloned Prs-like determinant and pap and prs determinants coding for P and Prs fimbriae (Hull et al., 1981; Lund et al., 1989; Karr et al., 1989). Thus, it appears that the $10 \mathrm{~kb}$ DNA fragment which resulted from BamHI cleavage of pIIIA9 carried most of the $F 165_{1}$ coding region. When this fragment was used as a radioactively labelled probe, it revealed identity with Pst I fragments of the chromosomal DNA and the cloned F165, fimbrial plasmid DNA. It is interesting to note that, in contrast to the uropathogenic $E$. coli strain $\mathrm{J} 96$ which contains the pap and prs operons, strain 4787 contains only one copy of the prs-related sequences operon.

The molecular mass of the $\mathrm{F} 165_{1}$ major fimbrial protein subunit was found to be $18.5 \mathrm{kDa}$, which is in good agreement with the value of $19 \mathrm{kDa}$ for one of the F165 complex components described by Fairbrother $e t$ $a l .(1988 a)$. No differences in size could be seen between F165, fimbriae isolated from the wild-type strain and from the K12 clones harbouring the cloned F165, DNA. It has been suggested that F165 complex is composed of two separate protein subunits (Fairbrother et al., 1988a). This would be consistent with the finding that $E$. coli strains associated with extra-intestinal infections, such as urinary disease, often produce more than one fimbrial antigen (Hacker, 1989; Svanborg-Edén \& De Man, 1987). As demonstrated by immunoblotting, strain 4787 expresses at least two fimbrial components: the $18.5 \mathrm{kDa}$ F165 fimbrial major protein subunit, and the $17 \mathrm{kDa}$ $\mathrm{F} 165_{2}$ major fimbrial protein subunit related to $\mathrm{S}$; the latter seems to be the predominant component in in vitro conditions and has recently been purified (D. Dubreuil and others, unpublished). Amino-terminal amino acid sequencing revealed that from residue 1 to 14 , the sequence of the major $18.5 \mathrm{kDa}$ protein subunit of fimbriae F165, closely resembled that of PapA (Båga et al., 1984), F11 (Van Die et al., 1987) and F7 2 (Van Die \& Bergmans, 1984) fimbriae.

Thus, the paper describes fimbrial antigen $\mathrm{F} 165_{1}$, which genetically belongs to the $\mathrm{P}$ fimbrial class, but possesses an adhesin having a different structure and receptor specificity from $\mathrm{Gal}(\alpha \mathrm{l} \rightarrow 4) \mathrm{Gal}$-binding $\mathrm{G}$-adhesins hitherto associated with $\mathbf{P}$ fimbriae. In fact, F165 -positive clones have been characterized and show adhesion to the terminal GalNAc $(\alpha 1 \rightarrow 3)$ GalNAc of Forssman antigen. Moreover, the recombinant clones recognize human erythrocytes of blood group $A_{1} P_{1}$, but not of group $\mathrm{OP}_{1}$. This indicates that the clones produce 
a G-adhesin or Prs recognizing an epitope shared by the globo-A and Forssman structures, e.g. the terminal GalNAc $(\alpha 1 \rightarrow 3)$ but not the P antigens. The Forssman antigen is a major constituent of sheep erythrocytes and is found in many species of animals. Thus, this Prs adhesin may have an important function in the infectious process of septicaemic strain 4787.

Similarly, some $\mathbf{P}$-antigen-recognizing strains, termed ONAP (for O-negative, A-positive) have been shown to recognize an epitope shared by globo-A and Forssman structures, e.g. GalNAc $(\alpha 1 \rightarrow 3)$ bound to $\operatorname{Gal}(\alpha 1 \rightarrow 4)$ Gal $\beta$-containing glycolipids (Lindstedt et al., 1989, 1991). Orino \& Naiki (1990) described the existence of two different P-fimbrial variant adhesin subunits that haemagglutinate sheep erythrocytes in the presence of D-mannose. One subunit recognizes Forssman glycosphingolipid but not $\mathbf{P}$ - and $\mathbf{P}^{\mathrm{k}}$-antigenic glycosphingolipids and the other recognizes a common carbohydrate epitope shared by Forssman glycosphingolipid, and by $\mathrm{P}$ - and $\mathrm{P}^{\mathrm{k}}$-antigenic glycosphingolipids.

The operon responsible for the fimbrial adhesin termed Prs (for P-related sequence) or Pap-2-recognizing Forssman antigen has been cloned from uropathogenic E. coli J96. The clones pPAP601 (Lund et al., 1988) and pJK 102 (Karr et al., 1989), both derived from uropathogenic $E$. coli isolate J96, were constructed differently and independently. The restriction maps of these clones suggest that the gene clusters are identical based on restriction site mapping. A structural difference between the pap and prs gene clusters was located within the papG region. prs $G$ encodes an adhesin-recognizing receptor on goat and sheep erythrocytes containing large quantities of Forssman glycolipids (Strömberg et al., 1991). The prslike clone pCJ7, derived from animal $E$. coli strain 4787 , has a restriction map similar to the prs and pap-2 clones, but with some differences at the $3^{\prime}$ end. It is not known as yet whether the adhesin expressed by pCJ7 differs structurally from PrsG. Nevertheless, the adhesin from pCJ7 must be sufficiently related to PrsG in order to recognize a similar class of erythrocytes but to differ from PrsG adhesin, as the latter does not agglutinate porcine erythrocytes (Strömberg et al., 1991).

F165-positive $E$. coli isolates have many of the virulence determinants found in extra-intestinal $E$. coli, such as aerobactin production and resistance to the bactericidal effects of serum and possess pap sequence alone or in association with afa or $s f a$ (Fairbrother et al., $1988 a$; Harel et al., 1991 a). However, the role of P and Prs adhesins in infections caused by F165-positive isolates is not known. The important role of $P$ adhesins in the physiopathology of $E$. coli pyelonephritis in humans has been reported in several studies. Few reports have described the presence of pap-related operons in porcine or bovine E. coli isolates (Harel et al., $1991 a$; Ott et al.,
1991). The strains with specificity for globo-A and the Forssman glycolipid were first isolated from the urinary tract of dogs (Garcia et al., 1982; Senior et al., 1988). P-positive $E$. coli have also been found in dogs with urinary tract infection (Low et al., 1988; Strömberg et al., 1990) and in avian septicaemia (Achtman et al., 1986). Gaastra and others (reported in Tennent et al., 1990) have demonstrated that $E$. coli isolated from dogs with urinary tract infections frequently express fimbriae that react with monoclonal antibodies directed against the fimbrial subunits of $\mathbf{P}$ fimbriae F12 and F13. Low et al. (1988) have found dog urinary tract infection $E$. coli isolates that contain genes homologous to pap but express a neuraminidase-sensitive binding phenotype. A high prevalence of PrsG-like specificities has been observed among wild-type uropathogenic (dog) E. coli (Strömberg et al., 1990).

Thus, a genomic DNA fragment coding for $F 165_{1}$, one of the fimbrial components of F165 complex, with a structural subunit of $18.5 \mathrm{kDa}$ has been cloned. The introduction of this Prs-like determinant into various wild-type hosts offers possibilities for the construction of novel live vaccines in animals, as already suggested for the $E$. coli $\mathrm{K} 88$ adhesin (Bakker et al., 1990).

We thank R. Lévesque, Université Laval, Québec, Canada for providing pMMB33, and V. Taliano, Société Canadienne de la Croix Rouge, for typing human blood. This work was supported in part by the Ministère de l'Enseignement supérieur et de la Science of the government of Québec and by grants to J.H. and J.F. from Conseil de Recherches en Sciences Naturelles et en Génie du Canada (OGP0025120 and OGP002294, respectively). J. Harel was supported by Fonds de la Recherche en Santé du Québec (870046).

\section{References}

Achtman, M., Heuzenroeder, M., Kusecek, B., Ochman, H., Caugant, D., Selander, R. K., Värs̈̈nen-Rhen, V., Korhonen, T. K., StuART, S., ØRSKOv, F. \& ØRSKov, I. (1986). Clonal analysis of Escherichia coli $\mathrm{O} 2: \mathrm{K} 1$ isolated from diseased humans and animals. Infection and Immunity 51, 268-276.

archambaud, M., CourcouX, P. \& Labigne-Roussel, A. (1988). Detection by molecular hybridization of PAP, AFA, and SFA adherence systems in Escherichia coli strains associated with urinary and enteral infections. Annales de l'Institut Pasteur/Microbiologie 139, 575-588.

Bakker, D., Van ZijdeRveld, G., Van Der Veen, S., Oudega, B. \& DE GRAAF, F. K. (1990). K88 fimbriae as carriers of heterologous antigenic determinants. Microbiology Pathogenesis 8, 343-352.

BÅga, M., Normark, S., Hardy, J., O'Hanley, P., Lark, D., Olsson, O., SCHOOLNIK, G. \& FALKOW, S. (1984). Nucleotide sequence of the PapA pilus subunit of human uropathogenic Escherichia coli. Journal of Bacteriology 157, 330-333.

BiRnBoim, H. C. \& Doly, J. (1979). A rapid alkaline extraction procedure for screening recombinant plasmid DNA. Nucleic Acids Research 7, 1513-1523.

Broes, A., Fairbrother, J. M., Jacques, J. \& Larivière, S. (1988). Isolation and characterization of a new fimbrial antigen (CS1541) from a porcine enterotoxigenic Escherichia coli $08: \mathrm{KX} 105$ strain. FEMS Microbiology Letters 55, 341-348. 
Chang, A. C. Y. \& Cohen, S. N. (1978). Construction and characterization of amplifiable multicopy DNA cloning vehicles derived from p15A cryptic miniplasmid. Journal of Bacteriology 134, 1141-1156.

Contrepois, M., Fairbrother, J. M., KaUra, Y. K. \& Girardeau, J. P. (1989). Prevalence of CS31A and F165 surface antigens in Escherichia coli isolates from animals in France, Canada, and India. FEMS Microbiology Letters 59, 319-324.

FAirbrother, J. M., LARIVIÈre, S. \& LALlier, R. (1986). New fimbrial antigen F165 from Escherichia coli serogroup O115 strains isolated from piglets with diarrhoea. Infection and Immunity 51, 10-15.

Fairbrother, J. M., Lallier, R., Leblanc, L., JacQues, M. \& LARIVIÈRE, S. (1988a). Production and purification of Escherichia coli fimbrial antigen F165. FEMS Microbiology Letters 56, 247-252.

Fairbrother, J. M., LARIVIÈre, S. \& JohnSON, W. M. (1988b). Prevalence of fimbrial antigens and enterotoxins in nonclassical serogroups of Escherichia coli isolated from newborn pigs with diarrhea. American Journal of Veterinary Research 49, 1325-1328.

FaIRBRother, J. M., Broes, A., JACQUES, M. \& LARIVIÈRe, S. (1989). Pathogenicity of Escherichia coli O115:KV165 isolated from pigs with diarrhea. American Journal of Veterinary Research 50, 1029-1036.

Frey, J., Bagdasarian, M., Feiss, D., Franklin, C. H. \& Deshusses, J. (1983). Stable cosmid vectors that enable the introduction of cloned fragments into a wide range of Gram-negative bacteria. Gene 24, 299-308.

Garcia, E., Bergmans, H. E. N., Van Den Bosch, J. F., Ørskov, I., VAN DER ZeIKST, B. A. M. \& GAASTRA, W. (1982). Isolation and characterization of dog uropathogenic Escherichia coli strains and their fimbriae. Antonie van Leeuwenhoek 54, 149-163.

HACKER, J. (1989). Genetic determinants coding for fimbriae and adhesins of extra-intestinal Escherichia coli. Current Topics in Microbiology and Immunology 151, 1-28.

Hacker , J., Schmidt, G., Hughes, C., Knapp, S., Marget, M. \& GOEBEL, W. (1985). Cloning and characterization of genes involved in production of mannose-resistant, neuramidase susceptible $(\mathbf{X})$ fimbriae from a uropathogenic Escherichia coli. Infection and Immunity 47, 434-440.

Harel, J., Daigle, F., Maiti, S., Desautels, C., Labigne, A. \& FAIBROTHER, J. M. (1991 a). Occurence of pap-, sfa-, and afa-related sequences among F165-positive Escherichia coli from diseased animals. FEMS Microbiology Letters 82, 177-182.

Harel, J., Lapointe, H., Fallara, A., Lortie, L. A., Bigras-Poulin, M., LARIVIÈRE, S. \& FAIRBROTHER, J. M. (1991 b). Detection of genes for fimbrial antigens and enterotoxins associated with Escherichia coli serogroups isolated from pigs with diarrhoea. Journal of Clinical Microbiology 29, 745-752.

Hull, R. A., Gill, R. E., Hsu, P., Minshew, H. \& Falkow, S. (1981) Construction and expression of recombinant plasmids encoding type 1 or D-mannose-resistant pili from a urinary tract infection Escherichia coli isolate. Infection and Immunity 33, 933-938.

Källenius, G., Möllby, R., Svensson, S. B., Winberg, J. Lundblad, A., Svensson, S. \& Cedergren, B. (1980). The $\mathrm{P}^{\mathrm{k}}$ antigen as receptor for the haemagglutination of pyelonephritogenic Escherichia coli. FEMS Microbiology Letters 7, 297-302.

KarR, J. F., Nowicki, B., Truong, L. D., Hull, R. A. \& Hull, S. I. (1989). Purified $P$ fimbriae from two cloned gene clusters of a single strain adhere to unique structures in the human kidney. Infection and Immunity 57, 3594-3600.

Korhonen, T. K., VÄISÄNen-Rhen, V., Rhen, M., Pere, A., PaRKxinen, F. \& FINNE, J. (1984). Escherichia coli fimbriae recognizing sialyl galactosides. Journal of Bacteriology 159, 762-766.

KUSHNER, S. R. (1978). An improved method for transformation of Escherichia coli with ColE1-derived plasmids. In Genetic Engineering, pp. 17-23. Edited by H. B. Boyer \& S. Nicosia. Amsterdam: Elsevier.

LABIGNE-Roussel, A., LARK, D., SchoolnIK, G. \& FALKow, S. (1984). Cloning and expression of an afimbrial adhesin (AFA-I) responsible for $\mathrm{P}$ blood group-independent, mannose-resistant haemagglutination from a pyelonephritic Escherichia coli strain. Infection and Immunity 46, 251-259.
LEGENDRE, N. \& MATSUDAIRA, P. (1988). Direct microsequencing from Immobilon-P transfer membrane. Biotechniques 6, 154-159.

Lindstedt, R., Baker, N., Falk, P., Hull, R., Hull, S., KarR, J., LefFler, H., SvanborG-EdéN, C. \& LaRson, G. (1989). Binding specificities of wild-type and cloned Escherichia coli strains that recognize globo-A. Infection and Immunity 57, 3389-3394.

Lindstedt, R., LaRson, G., Falk, P., Jodal, U., LeFFler, H. \& SvanborG, C. (1991). The receptor repertoire defines the host range for attaching Escherichia coli that recognize globo-A. Infection and Immunity 59, 1086-1092.

LorTiE, L. A., DubreuIL, J. D. \& HAREL, J. (1991). Characterization of Escherichia coli strains producing heat-stable enterotoxin b (STb) isolated from humans with diarrhea. Journal of Clinical Microbiology 29, 656-659.

Low, D. A., Braaten, B. A., Ling, G. V., Johnson, D. L. \& Ruby, A. L. (1988). Isolation and comparison of Escherichia coli strains from canine and human patients with urinary tract infections. Infection and Immunity 56, 2601-2609.

Lund, B., Marlund, B. I., STrömberg, N., Lindberg, F., Karlsson, K. A. \& Normark, S. (1988). Uropathogenic E. coli can express serologically identical pili of different receptor binding specificities. Molecular Microbiology 2, 255-263.

Maniatis, T., Fritsch, E. F. \& SAmbrooK, J. (1983). Molecular Cloning: A Laboratory Manual. Cold Spring Harbor, NY: Cold Spring Harbor Laboratory.

Miller, J. H. (1972). Experiments in Molecular Genetics. Cold Spring Harbor, NY: Cold Spring Harbor Laboratory.

OrINo, K. \& NaIKI, M. (1990). Two kinds of P-fimbrial variants of uropathogenic Escherichia coli recognizing Forssman glycosphingolipid. Microbiology and Immunology 34, 607-615.

ØRSKOV, I. \& ØRSKOV, F. (1985). Escherichia coli in extraintestinal infections. Journal of Hygiene 95, 551-575.

ØRSKOV, I. \& ØRSKOV, F. (1983). Serology of Escherichia coli fimbriae. Progress in Allergy 33, 80-105.

Ott, M., Bender, L., Blum, G., Schmittroth, M., Achtman, M., TSCHAPE, H. \& HACKER, J. (1991). Virulence patterns genetic mapping of extraintestinal Escherichia coli $\mathrm{K} 1, \mathrm{~K} 5$, and $\mathrm{K} 100$ isolates: use of pulse-field electrophoresis. Infection and Immunity 59, 2664-2672.

Rhen, M., Van Die, I., Rhen, V. \& Bergmans, H. (1985). Comparisons of the nucleotide sequences of the genes encoding the KS71A and F7, fimbrial antigens of uropathogenic Escherichia coli. European Journal of Biochemistry 151, 573-577.

RHEN, M., KLEMM, P. \& KorHONEN, T. K. (1986). Identification of two new hemagglutinins of Escherichia coli, $N$-acetyl-D-glucosaminespecific fimbriae and a blood group $\mathrm{M}$-specific agglutinin, by cloning the corresponding genes in Escherichia coli K-12. Journal of Bacteriology 168, 1234-1242.

Senior, D., Baker, N., Cedergren, B., Falk, P., Larson, G., Lindstedt, R. \& Svanborg-Eden, C. (1988). Globo-A - a new receptor specificity for attaching Escherichia coli. FEBS Letters 237, 123-127.

SoUTHERN, E. M. (1975). Detection of specific sequences among DNA fragments separated by gel electrophoresis. Journal of Molecular Biology 98, 503-517.

Strömberg, N., MARKLund, B.-I., Lund, B., Ilver, D., Hamers, A., GaAstra, W., Karlsson, K.-A. \& Normark, N. (1990). Hostspecificity of uropathogenic Escherichia coli depends on differences in binding specificity to $\mathrm{Gal} \alpha 1-4 \mathrm{Gal}$-containing isoreceptors. $E M B O$ Journal 9, 2001-2010.

Strömberg, N., NyHolm, P.-G., Pascher, I. \& Normark, S. (1991) Saccharide orientation at the cell surface affects glycolipid receptor function. Proceedings of the National Academy of Sciences of the United States of America 88, 9340-9344.

Svanborg-Edén, C. \& De Man, P. (1987). Bacterial virulence in urinary tract infection. Infection and Disease Clinical North American 1, 731-750.

Tennent, J. M., Hultgren, S., Göransson, M., Uhlin, B. E. \& NORMARK, S. (1990). Genetics of adhesin expression in Escherichia coli. In Molecular Basis of Bacterial Pathogenesis, pp. 80-135. Edited by B. H. Iglewski \& V. L. Clark. San Diego: Academic Press. 
Towbin, H., Staehelin, T. \& GoRdon, J. (1979). Electrophoretic transfer of proteins from polyacrylamide gels to nitrocellulose sheets: procedure and some applications. Proceedings of the National Academy of Sciences of the United States of America 78, 4350-4353.

VÄISÄNEN-RHEN, V., Elo, J., VÄISÄNEN, E., SIITONEN, A., ØRSKOV, I., Ørskov, F., Svenson, S. B., MÄKelä, P. H. \& Korhonen, T. K. (1984). P-fimbriated clones among uropathogenic Escherichia coli strains. Infection and Immunity 43, 149-155.
Van Die, I. \& Bergmans, H. (1984). Nucleotide sequence of the gene encoding the $\mathrm{F}_{2}$ fimbrial subunit of a uropathogenic Escherichia coli strain. Gene 32, 83-90.

Van Die, I., Hoekstra, W. \& Bergmans, H. (1987). Analysis of the primary structure of P-fimbrillins of uropathogenic Escherichia coli. Microbial Pathogenesis 3, 149-154. 